British Journal of Marketing Studies (BJMS)

Vol. 8, Issue 3, pp.29-53 May, 2020

Published by ECRTD- UK

Print ISSN: 2053-4043(Print), Online ISSN: 2053-4051(Online)

\title{
INTERNET BANKING SERVICE QUALITY AND CUSTOMER RETENTION IN DEPOSIT MONEY BANKS IN RIVERS STATE- NIGERIA
}

\author{
${ }^{* A}$ Amadi Ezechirinum, ${ }^{\mathrm{A} A n u c h a}$ Victor C., ${ }^{\mathrm{B}}$ Uwabor Osagie Leslie

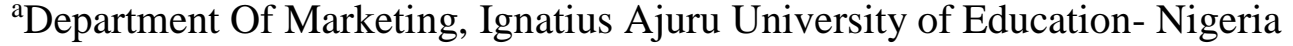 \\ ${ }^{\mathrm{b}}$ School of business education. Department of accounting, Federal College of Education Omoku, \\ Rivers State-Nigeria \\ *Corresponding Author: ezvidik@yahoo.com \\ P.O. Box 488 Uniport Post Office, Port Harcourt - Nigeria
}

\begin{abstract}
This study investigates the relationship between Internet Banking Service Quality and Customer Retention in Deposit Money Banks in Rivers State. The objectives of the study were to investigate the influence of internet service efficiency and website design on Customer Retention. The study adopted the quasi-experimental research design which employed the cross sectional survey design. The choice of this survey approach is because it will scientifically look at the situation on ground and will empirically analyze it to get result that can be attributable to the accessible population. Based on the research questions, a research questionnaire was designed and one hundred and ninety (190) copies were distributed to the customers of the banks who constituted the populationof study, the researcher purposively administered ten (10) copies each to customers of the nineteen (19) deposit money banks in Rivers State. A total of one hundred \& sixty-nine (169) copies of the distributed questionnaire were retrieved. These copies were analyzed and the hypotheses were tested using the Kendal's Correlation Coefficient with the aid of SPSS Version 23.0. The result revealed that; there is a significant relationship between internet banking service efficiency and referral, internet banking service efficiency and resistance to competitive pressure, Internet banking website design and referral, Internet banking website design and resistance to competitive pressure. The result also revealed that customer technology adoption positively influences the relationship between internet banking service quality and customer retention in deposit money banks in Rivers State. The study concluded that consumer orientation should be applied whenever; banks are adopting new techniques that will service the need of their customers for better satisfaction. The study recommends that Banks should invest more on technologies that will ensure efficiency in serving customer and overall satisfactions of the customers. Customer satisfaction should be kept in mind as banks upgrade existing systems or while buying new systems altogether.
\end{abstract}

KEYWORDS: Internet banking, customer retention, customer satisfaction

\section{INTRODUCTION}

\section{Overview}

The general expectation of banks to compete actively and to grow continually, especially in this era of globalization, is informed by the capabilities of these banks and their competence in creating 
Vol. 8, Issue 3, pp.29-53 May, 2020

Published by ECRTD- UK

Print ISSN: 2053-4043(Print), Online ISSN: 2053-4051(Online)

and retaining loyal customers. This as such constrains the banks to strive to create a competitive advantage through innovative efforts and creativity so as to retain loyal customers. Oliver (1999) defined customer retention as "the commitment of the customers to repurchase a product or service consistently in the future", although situations do arise which hypothetically causes behavioral changes like being swayed by other individuals or marketing efforts steered by competitors. Guiltinan et al. (1997) also found that satisfied customers were more probable to repeat the purchase of products or services and even become loyal customers and not to think of switching to another banks.

Globalization and technology advancements are possiblychallenging the financial sector, mostly the banks. The stern competition combined with customer demands has steered the banking industry to further challenges. The dip in the global economic coupled with diminishing margins is a disquietto banks globally. Globally, banks are striving to cut costs and increase margins in order to survive in this highly competitive environment. The Internet, today, is virtually a crucial channel for the sale of goods and services (Parasuraman, 2000). Internet banking has left the realm of being a phenomenon to being a pre-requisite for the banking sector ideating as the most comprehendible mode of future banking. Internet banking currently stands out as the logical and most cost effective channel for banks and their customers. A noteworthy feature of internet banking is its allowance of customers to access their bank accounts 24/7, which is a new experience and intrinsically inspiring.

Internet banking is a system that facilitates bank customers in accessing their accounts and general information regarding bank products and services via a personal computer or any other electronic internet enabled devices such as mobile phones (Wijayarathne, 2015). It offers banking at the go, enabling transactions and payments over the internet through a bank's website (Devi \& Revathy, 2011). According to Premarathne and Gunathilake (2016), internet banking is defined as a set of technological tools offered by financial institutions for its customers to do banking transactions via computers using an internet connection. Internet banking is an integrated system that offers customers flexible, suitable and low-cost platforms with integrated services of online personal banking such as online checking and saving accounts, certificate of deposit, money market accounts, investment services and other related financial services (Bhattacherjee, 2001).

Internet banking involves customers interacting via a network technology, while traditional banking entails interactions with customers on a non-website-based setting. However, internet banking services possess a distinctive characteristic which traditional banking services lack. For example, internet banking grantsthe customers an avenue to carry out a range of banking activities electronically at one's convenience with low handling cost (Angelakopoulos \& Mihiotis, 2011; Narayanasamy, Rasiah \& Tan, 2011; Nor \& Pearson, 2008; Weir, Anderson\& Jack, 2006; Yoon \& Steege, 2013). In this way, internet banking plays an important role in reducing operating and fixed costs (Chen, Hsiao \& Hwang, 2012; Fonseca, 2014; Zhao, Hanmer-Lloyd, Ward \& Goode, 2008;Zhao, Koenig-Lewis, Hanmer-Lloyd \& Ward, 2010) and helps the bank in building better relationship with their customers (DeYoung, Lang \& Nolle, 2007; Ribbinket al.Ribbink, Van Riel, Liljander \& Streukens, 2004; Rod \&Ashill, 2010; Rodet al. Rod, Ashill, Shao \& Carruthers, 2009). 
British Journal of Marketing Studies (BJMS)

Vol. 8, Issue 3, pp.29-53 May, 2020

Published by ECRTD- UK

Print ISSN: 2053-4043(Print), Online ISSN: 2053-4051(Online)

Service quality according to Jelena, Natalja and Konstantins (2013) involves the customer judgment about a service provider's overall excellence. It is regarded as a critical factor that distinguishes competitors (Nagabhushanam, 2011). In late eighties, service quality was opined to be the degree in which customer's normative expectation could be differentiated from their perception of service performance (Parasuraman, Zeithamal\& Berry, 1985). Sharma and Malviya(2014)pointed out that the service quality judgment is a result of the difference amid customer expectation and perception of the actual performance. Islam andAhamed (2003) noted that there exists a significant difference between expected and perceived service quality of banks. Conferring to Nagabhushanam, (2011), customer service is a dynamic interactive process which needs continuous improvements. Further, he expounded that quality is paramount in selling a product and it is a factor that sways the purchasing behavior of the customer.

Service Quality is the primary factor that defines the achievements and shortcomings of electronic commerce (Santos 2003). Failure to assess service quality is detrimental to the growth of the internet banking. Customers are apt to demand equal or higher standard of service quality based on-line than the traditional services, (Santos, 2003). Traditional service quality varies from eservice quality when dealing with delivery of services, former being the traditional interaction and the latter being delivered primarily through websites.

From empirical point of view, many studies have been done regarding the construct and concept of internet banking with other construct and practices. For instance; Arbore and Busacca, (2009) studied "Consumer perception of internet banking Self-Service outcomes". Culiberg and Rojs`ek, (2010) examined internet banking practices: Accessing Customer Satisfaction with Internet-Based Service Encounters. Akhtar, Hunjra, Akbar, Rehman, and Niazi (2011), tested "the effect of service quality of Islamic banking on customer satisfaction". Korda and Snoj (2010) examined "the relations among service quality, value and satisfaction". It is therefore factual that from the listed empirical studies, most studies have not critically looked at how internet banking service quality has better the retention of customers and consequently, patronage of the banks. A literature gap therefore exists and our departure point is to empirically investigate the relationship between internet banking service quality and customer retention of deposit money banks in Rivers State.

\section{Statement of the Problem}

Despite the upsurge in internet banking users, the customer acceptance of internet banking has not yet reached the expected levels. Collectively, poor service quality coupled with customer dissatisfaction remains concerns that hinder the adoption of internet banking (Calisir \& Gumussoy, 2008; Li-hua, 2012; Zhao, Koenig-Lewis, Hanmer-Lloyd \& Ward, 2010). In fact, the main hurdle for customer intention to adopt internet banking services is linked to the user's convenience. Furthermore, customers are struggling to change their habits, deeds, the way they interact with its internet banking services offer (Alsajjan \& Dennis, 2010; Chemingui, 2013; Chen \& Teng, 2013; Hanafizadeh, Keating\&Khedmatgozar, 2014; Khalil, Sutanonpaiboon, \&Mastor, 2010; Nor \& Pearson, 2008). The potential customers' readiness to adopt the technology is also a significant factor (Al-Ajam and MdNor, 2015; Al-alak, 2014; Chiou\& Shen, 2012; Giordani, Floros \& Judge, 2014; Liu, Jing \& Huang, 2005; Rezaei, Amin \& Wan Ismail, 2014). Interestingly, Karjaluoto, Mattila and Pento, (2002) found lack of consumer skills and experience with computers and 
British Journal of Marketing Studies (BJMS)

Vol. 8, Issue 3, pp.29-53 May, 2020

Published by ECRTD- UK

Print ISSN: 2053-4043(Print), Online ISSN: 2053-4051(Online)

technologies, which sway the consumer attitude toward internet banking. In addition, interpersonal, social network, security concerns (Hasim \& Salman, 2010), habit coupled with personality traits (McNeish, 2015) are the main criteria which sway customers to use internet banking. In fact, the lack of cognizance and understanding of the benefits of internet banking services is also anoutstanding issue (Guriting \& Ndubisi, 2006; Laforet \& Li, 2005; Liu, Jing \& Huang, 2005; Suzanne Harrison, Peter Onyia \& Tagg, 2014; Thakur, 2014; Wuet al. Wu, Tao\& Yang, 2012; Zhao, Hanmer-Lloyd, Ward, \& Goode, 2008). Many studies are yet to focus their attention on how this concept of internet banking can boost customer patronage and sustained retention. This study therefore seeks to evaluate the effect of internet banking service quality on customer retention in the banking sector in Rivers State.

\section{Conceptual Framework}

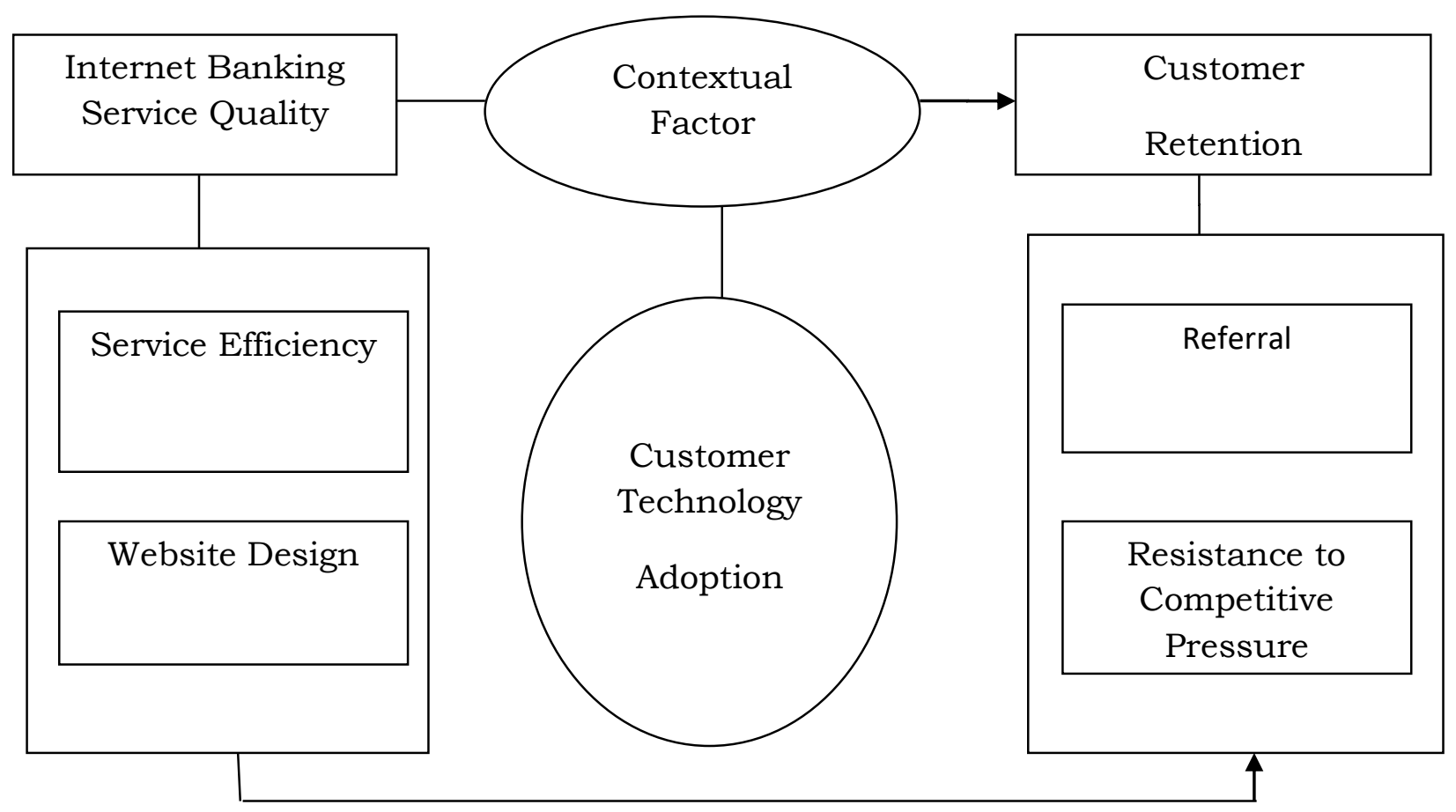

Figure 1.1: Conceptual Framework on the Relationship between Internet Banking Service Quality and Customer Retention in Deposit Money Banks in Rivers State

Source: Researcher's Conceptualization from Review of Related Literature, 2019

\section{Objectives of the Study}

The general objective of this study was to examine the relationship between the internet banking service quality and customer retention in deposit money banks in Rivers State. Concisely, the following specific objectives include:

i. $\quad$ To examine the relationship between service efficiency and customer retention of deposit money banks in Rivers State.

ii. To examine the relationship between website design and customer retention of deposit money banks in Rivers State. 
British Journal of Marketing Studies (BJMS)

Vol. 8, Issue 3, pp.29-53 May, 2020

Published by ECRTD- UK

Print ISSN: 2053-4043(Print), Online ISSN: 2053-4051(Online)

iii. To determine the extent to which consumer technology adoption influence the relationship between internet banking service quality and customer retention of deposit money banks in Rivers State.

\section{Research Questions}

In this section of the study, the following research questions were stated;

i. What is the relationship between service efficiency and customer retention of deposit money banks in Rivers State?

ii. How does website design relate with customer retention of deposit money banks in Rivers State?

iii. To what extent does customer technology adoption influence the relationship between internet banking service quality and customer retention of deposit money banks in Rivers State?

\section{Research Hypotheses}

The following hypotheses are formulated to guide the study:

Ho1: There is no significant relationship between service efficiency and referral in deposit money banks in Rivers State.

Ho2: There is no significant relationship between service efficiency and resistance to competitive pressure in deposit money banks in Rivers State.

Hoz: There is no significant relationship between website design and referral in deposit money banks in Rivers State.

Ho4: There is no significant relationship between website design and resistance to competitive pressure in deposit money banks in Rivers State

Hos: Customer technology adoption does not significantly influence the relationship between internet banking service quality and customer retention in deposit money banks in Rivers State.

\section{REVIEW OF RELATED LITERATURE}

\section{Theoretical Review}

Technology Acceptance Model has been developed by Davies (1989) as one of the most popular research models to predict use and acceptance of information systems and technology by individual users.TAM has been studied extensively and verified by numerous researches who looked at the individual technology acceptance behaviour in different information systems constructs. In TAM models, two factors are relevant when it comes to computer use behaviours, these are perceived usefulness and perceived ease of use. Perceive usefulness as defined by Davies (1989) regards the likely user's subjective probability if their job or life performance would be enhanced by using a specific application system. Perceive ease of use commonly denoted as EOU describes the extent to which the eventual user expects the target system to be effortless.According to TAM, ease of use and perceived usefulness are seen as the essentialfactors of actual system use. These two factors are subjective by external variables. The main external factors that are usually manifested are factors concerning social, cultural, and political issues. Social factors comprise language, skills and facilitating conditions. Political factors are mainly the impact of using technology in politics and political crisis. The approach to use is concerned with the user's assessment of the appeal of employing a specific information system application. Behavioral 
British Journal of Marketing Studies (BJMS)

Vol. 8, Issue 3, pp.29-53 May, 2020

Published by ECRTD- UK

Print ISSN: 2053-4043(Print), Online ISSN: 2053-4051(Online)

intention is the measure of the likelihood of a person employing the application.The model underpins this study in the sense that it espouses the relevance of the knowledge and understanding of information technology to the value of internet banking practices to customers which in turn breeds satisfaction, retention and continuous patronage of the banks by their customers

\section{Conceptual Framework}

\section{Internet Banking Service Quality}

Historically, the initiation of the first Automated Teller Machine (ATM) in Finland marked the start of a new banking channel, which placed Finland as the forerunner in E-Banking, before it became extensively used in other developed and developing countries (Sharma \& Malviya, 2014). Lately, E-Banking, or the delivery of financial services by electronic systems, has spread amongst customers as perswiftadvancement in information technology and through competition amongst banks (Mahdi, Rezaul, \& Rahman, 2010). Lustsik (2004) defines internet banking services to be a selection of e-channels for conducting banking transactions via Internet, telephone, TV, mobile, and computer. Banking customers' desires and outlookswhen it comes to service are growing, as technology advances and improve. Nowadays, customerswant to operate and do their banking transactions irrespective of the location without going to the bank, without being time bound andrestricted to the bank's working hours, and to do all their payments (purchasing, bills, stocks) in a fast and cost-effective way. Consequently, internet banking services quality ought to be categorized by independence, freedom, elasticity and flexibility, to lodge these desires (Khalfan \& Alshawaf, 2004).

Internet banking service quality is recognized as a 'critical criterion for setting up and sustaining satisfying relationships between a bank and her valued customers' (Lassar, Manolis, \& Winsor, 2000). It is anindividual phenomenon dependent on the individual opinions of customers (Schneider \& White, 2004), and this explains why there are several definitions regarding internet banking service quality (Radomir, Wilson, \& Mircea, 2011). Some recent definitions of internet banking service quality include that of Siddique, Karim and Rahman (2011) which states that"the consumer's overall impression of the relative inferiority or superiority of a bank and its services", Wei (2013) argued that it is a measure of the extent to which the internet services delivered fulfills the customers' expectations, why Culiberg and Rojšek (2010) defined it to be customer's judgment about a service and Zeithaml and Parasuraman(2004) in their own view, defined it as the difference between customers' expectations of this internet service and their perceptions of actual service performance.

Many researchers consider that internet banking service quality is an obscure concept, and there are substantial debates among researchers on how to conceptualize this phenomenon. It is also recognized in literature that internet banking service quality is a dynamic, multidimensional concept, incorporating a number of aspects of both past and present internet service experiences (Ab.Aziz, Shukor, \& Abdullah, 2014). Literature is replete with study findings that internet banking service quality still is a critical factor in the success of most bank businesses. Kadir, Rahmani, and Masinaei (2011) opined that internet banking service quality is avital tool for assessing customer satisfaction and also impacts performance of the banks. High internet banking service quality result into competitive advantage as customers feel satisfied and consequently are 
British Journal of Marketing Studies (BJMS)

Vol. 8, Issue 3, pp.29-53 May, 2020

Published by ECRTD- UK

Print ISSN: 2053-4043(Print), Online ISSN: 2053-4051(Online)

more probable to further patronize the bank, to endorse them to others and to overlook competitors' offers (Radomir, Wilson \& Mircea, 2011).

In banking sector, it is imperative to fathom the factors leading to satisfaction, which will obviously lead to loyalty (Van Riel, Liljander \& Jurriens, 2001). The competition grows dailyvisà-vis services in banking sector. Observation has shown that Information Technology is rapidly replacing human labor (Jun \&Cai, 2001). It has been demonstrated that more thoughts need to be given to customer's satisfaction and loyalty by organizations (Parasuraman \& Grewal, 2000). Mols (2000) reasoned that the home-based Internet banking might give rise to strong relationships with customers since customer expectations have an aptness to change over time. Likewise, service quality is another essentialconcern while gaining customer satisfaction and retention. Maintaining service quality is exceedingly necessary within this present andvery competitive banking sector (Mefford, 1993). For this, bankers need to recognize the attributes affecting customer loyalty. The dimensions of internet banking service quality adopted in this study are service efficiency and website design.

\section{Service Efficiency}

According to Zeithaml and Parasuraman (2004), efficiency means ability of the customers to get the web site, find the desired product and information within a minimum effort(Santos, 2003; Wu, Tao\& Yang, 2012; Sharma \&Malviya, 2014; Toor, Hunain, Hussain, Ali \& Shahid, 2016).Giordani, Floros and Judge (2014) suggest that service efficiency can make a positive influence on the satisfaction level of the customers. Also Kadir, Rahmani and Masinaei(2011) hypothesized that service efficiency has a significant positive effect on customer satisfaction.

\section{Website Design}

According to Culiberg and Rojs`ek (2010), the perception of customers about website quality is based on features in a website that meet customers' needs and impress the total excellence of that website. Sikdar, Kumar and Makkad (2015), mentioned that the multiple dimensions of website quality can be categorized as security, enjoyment, information quality, ease of use, and service quality which are reflected in the design of the website. At the same time, website design is an important determinant of website features, and is critical in achieving the quality of service offered to customers through the website. Crucial features in a successful website design are aesthetic appearance, navigation, and an organized and well-managed content display(Rezaei, Amin\& Wan Ismail, 2014). Attractive and interesting effects in e-commerce websites motivate consumers to engage in online shopping activities (Asiyanbi \& Ishola, 2018). According to Toor, Hunain, Hussain, Ali, and Shahid (2016), website features have an important influence on online purchase intention. Plus, an informative website enables customers to compare and evaluate product alternatives, thereby increasing customer satisfaction and contributing to online purchase intention (Malek, Nik, \& Nik, 2011). The quality of information offered by a brand on online shopping websites is also an important factor. One particular study reveals that information quality has the highest influence on customer satisfaction among all website quality dimensions (Radomir, Wilson \& Mircea, 2011). 
British Journal of Marketing Studies (BJMS)

Vol. 8, Issue 3, pp.29-53 May, 2020

Published by ECRTD- UK

Print ISSN: 2053-4043(Print), Online ISSN: 2053-4051(Online)

\section{Customer Retention}

According to the New Webster Dictionary (1994), retention is seen to be maintaining a customer in an exchange transaction. It could also mean "the act of being a regular customer to a shop. In a highly competitive industry, such as banking, satisfying the customers should be the primary focus of firms that wish to retain their customers (Johns \& Tyas, 1996; Kivela, Inbakaran, \& Reece, 1999; Sulek \& Hensley, 2004).

Service organizations can enhance customers' retention by creating value in product offerings to meet customers' expectations and satisfy their needs. Fishbein and Ajzen (1975) view consumers ${ }^{\text {ee }}$ purchase intention as an important pointer for predicting consumer behavior. Customer retention describes the prospect that the consumer will be willing to buy a specific product in the future. Zeithaml (1988) stressed that merchandize value perceptions steers purchase intentions and purchase behavior in organizations. Literature on regulatory focus theory abound (Wirtz \& Lwin, 2009; Brockner, Higgins, \& Low, 2004; Aaker \& Lee, 2006; Grewal et al, 2010; Lee, Aaker, \& Gardner, 2000; Lockwood, Jordan \& Kunda, 2002; Friedman \& Forster, 2001).

Consumer research has examined the influence of merchandise value perceptions when it comes to consumer behavior (e.g., Dodds et al, 1991; Zeithaml et al, 1996) and revealedthat consumer' evaluations of merchandise or product value influences their patronage and retention in traditional stores. Therefore, customer retention is found to be swayed by product value. Consumers' retention can similarly be grasped as a connection between their attitude towards a product and its actual purchase. According toFishbein and Ajzen (1975), gauging customers' retentionis made possible through three notable measurement items which are: possible to buy, consider buying, andintended to buy. For the purpose of this study, we hereby adopt the variables of referral and resistance to competitive pressure as the measures of customer retention.

\section{Referral}

Referral marketing is a method of promoting products or services to new customers through referrals, usually word of mouth. Such referrals often happen spontaneously but businesses can influence this through appropriate strategies. Consumers frequently rely on word of mouth and referrals (active) and observational learning (passive) from other consumers when making a purchase decision (Devi \& Revathy, 2011).

\section{Customers' Resistance to Competitive Pressure}

Customer loyalty is defined as "a deeply held commitment to re-buy or re-patronize a preferred product/service consistently in the future, therebycausing repetitive same-brand or same brand-set purchasing, despite situational influences and marketing efforts having the potential to cause switching behavior" (Oliver, 1999). This definition captures not only the spirit of global customer loyalty but also emphasizes the attitudinal ("...deeply held commitment...") as well as the behavioral (“...causing repetitive same-brand or same brand-set purchasing...") components of customer loyalty. The attitudinal component of customer loyalty is further developed by partitioning it into cognitive and affective dimensions. It is expected thatcognitive and affective loyalties to have independent influences on customer retention. 
British Journal of Marketing Studies (BJMS)

Vol. 8, Issue 3, pp.29-53 May, 2020

Published by ECRTD- UK

Print ISSN: 2053-4043(Print), Online ISSN: 2053-4051(Online)

\section{Internet Banking Service Quality and Customer Retention}

One main objective of this research is to understand to what extent the quality of electronic (internet) services offered by banks would affect the satisfaction, sustained patronage and retention of the customer in the Rivers State. Conferring to Grönroos (1998), there is a steady and positive relationship encompassing both the Internet banking service quality and customer retention. Indeed, Parasuraman, Zeithaml, and Berry (1988) also determined in a study that the relationship amongst quality of service and customer satisfaction and retention is one which is very sturdy and durable. Jain and Gupta (2004) when examining the relationshipbetween quality of service and satisfaction, came to a conclusion that great customer satisfaction and consequent loyalty immensely relies upon receiving a better and higher quality service.

Several studies highlightedthe relationships between internet banking services and customer loyalty. Asiyanbi and Ishola (2018)in their research demonstrated that when using E-Banking services, the satisfaction degree of customers in the banking sector does increase. Similarly, Ranaweera and Neely (2003) substantiatedthat customers' satisfaction starts with the quality of Eservice. Likewise, Bei and Chiao (2006) acknowledged a major relationship amongst the quality of the service and the customer satisfaction degree of customers. Finally, Zhou (2004) specified that the E-Banking service quality linked to reliability has a substantialinfluence on the degree of customer satisfaction and retention.

\section{Internet Banking Service Efficiency and Customer Retention}

This pertains to the effective delivery of the internet customers' services obtainable so as to fulfill their needs, resolve their quarries and solve complains etc. effective customer services are very attractive and helpful in motivating customers' patronage. Efficiency also encompasses the timeliness for instance,speedy action to customers complains, mailing transactions slips instantly and returning a call to the customer swiftly in order to resolve their matter (Al-Hawari\& Ward, 2006). Similarly, one of the significant variables capable of prompting customers to consistently patronize internet-banking product or package is the service efficiency and prompts responsiveness, which deals with the willingness or readiness to assist customers and provide prompt service.

According to Chaoprasert and Elsey (2004), efficiency is an essential ingredient for bank to appealto more customers and to have an enduring long success. Hossain and Leo (2009), defines efficiency in general as the ability to provide quick and accurate solution to the specific needs of the customers, because the consumer lacks sufficient expertise for processing of some basic internet services. Efficiency in internet banking services thus centers on the ability of the service provider to conform to customers' specifications and needs, respond to them without errors in minutes plus immediate delivery to the customer (Jayawardhena, 2004). In electronic service quality, efficiency measures -the level of assistance, simplicity, speed and accuracy of the on-line platform in ensuring the provision of customers' needs and anticipated satisfaction (Mishra, 2009), in addition to the company's ability to offer a solution to customers' needs electronically (Rajput \& Gupta, 2011), efficiency reflects the professionalism of the business in living up to their expectations and providing the perfect internet structure that will enable the customers meet their 
British Journal of Marketing Studies (BJMS)

Vol. 8, Issue 3, pp.29-53 May, 2020

Published by ECRTD- UK

Print ISSN: 2053-4043(Print), Online ISSN: 2053-4051(Online)

internet transaction needs which in turn guarantees their loyalty and retention (Yang \& Fang, 2004). Based on the above, the ensuing hypotheses are hereby stated;

Ho1: There is no significant relationship between service efficiency and referral in deposit money banks in Rivers State.

Ho2: There is no significant relationship between service efficiency and resistance to competitive pressure in deposit money banks in Rivers State.

\section{Website design and Customer Retention}

The website design pertains to the visual aesthetics of web pages (Agarwal, Rastogi\&Mehrotra, 2009). According to Asad, Mohajerani andNourseresh, 2016, Ho and Ko, (2008), Poon, (2007), graphics, quality of images and videos, symbols, colors, animations are of paramount importance for the attractiveness and success of the website which in turn breeds customers' satisfaction and patronage. Alawneh, Al-Refai and Batiha, (2013) also argued that these can give the user a good impression on the website and may have a significant bearing on online satisfaction (Asiyanbi \& Ishola, 2018). According to Datta, (2010), quality of design is an important factor for user's trust. Khalfan and Alshawaf, (2004) suggested that users do not appreciate the website design that will have negative impact on the frequency of their visits to the website. Sharma and Malviya, (2014) have indicated that in e-commerce, customers are incline to think that the company that has invested in the design of their websites is likely to process electronic transaction successfully, thus customers are motivated to patronize such companies.

Further Sikdar, Kumar and Makkad, (2015) found empirically that website's design positively influences customer's online trust towards financial institutions. Particularly website design discusses all interactive components of the website with the customer i.e. user navigation, providing passable information \& customer order processes, information content, information nature \& the type of graphics are other components of this indication which in turn positively affect e-satisfaction and sustained patronage (Sharma, 2011). Liao and Cheung, (2002) have argued that website design quality exhibited positive direct effects on pleasure arousal \& perceived information quality and on satisfaction and repeated patronage. From the standpoint of human computer interactions, the type of website designing is vastly important and influences intensively on users' performance (Jun, Yang \& Kim, 2004).

Toor, Hunain, Hussain, Ali and Shahid, (2016) consider that website designing holds a vital role in inviting, retaining and improving customers' curiosity in website (Poon, 2007). Website designing aims at an attractive and enjoyable appearance (Asad, Mohajerani\&Nourseresh, 2016). More studies on internet service quality have especially focus on website designing and all authors agree that websites should be designed in a manner to enhance customers' conception on website and its services (Datta, 2010). Furthermore, desired website designing would increase accessibility and plays a critical role in its attractiveness and enhance customers' patronage (Toor, Hunain, Hussain, Ali \&Shahid, 2016). One of the best ways to improve website designing is that customers should be asked to evaluate it (Ho \&Ko, 2008). Various researchesregarding website designing and authors have made known the efficacy of website designing on customers' satisfaction and 
British Journal of Marketing Studies (BJMS)

Vol. 8, Issue 3, pp.29-53 May, 2020

Published by ECRTD- UK

Print ISSN: 2053-4043(Print), Online ISSN: 2053-4051(Online)

sustained retention (Sikdar, Kumar \&Makkad, 2015). In respect to the aforementioned studies, we therefore state the following hypotheses:

Ho3: There is no significant relationship between website design and referral in deposit money banks in Rivers State.

Ho4: There is no significant relationship between website design and resistance to competitive pressure in deposit money banks in Rivers State.

\section{Moderating influence of Customer Technology Adoption on the Relationship between Internet Banking Service Quality and Customer Retention}

Rogers and Shoemaker (1971) posits that consumers go through "a process of knowledge, persuasion, decision and confirmation" so as to be ready to accept a product or service. Individuals who are skilled and constantly using the internet significantly impact the acceptance of Internet banking services. Users skilled in using computers and the Internet will sway them to adopt Internet banking services (Lassar et. al, 2005). The receptions of internet banking services can be examined bypinpointing the reasons of the use of internet banking (Eriksson et. al, 2005).

Shih and Fang (2003) claimed that the use of Internet banking as regards to the factors of behavioral intention, which is the actual application of banking transaction, subjective norms, attitude, perceived and relative advantages of the Internet banking, and normative influences. They also concurred with Wungwanit-Chakorn (2000) that compatibility, efficiency and complexity of the Internet banking will sway the acceptance of the Internet banking usage. E-banking is viewed as an important delivery channel that presents one-stop services and information unit to gain competitive lead in banking sector (Malek AL-Majadi and Nik Kamariah Nik Mat, 2011).

Gao and Owolabi (2008) vie thatat present relevant factors influentialto the adoption of Internet banking in Nigeria comprise the level of awareness or consideration, the accessibility to computers and the Internet, costs, convenience, privacyand the availability of knowledge and support concerning internet banking. Equally, Al-Somali et al. (2008) made known that low cognizance of Internet banking is a critical factor in swaying customers not to adopt internet banking and Katri (2003) pointed that most important factors daunting the use of Internet banking is actually the lack of Internet access and security challenges of Internet banking. According to Gan et al. (2006), prior studies acknowledged that user input factors are dependent on control, enjoyment and intention to use. Control could depict the amount of effort and involvement required by consumers in electronic banking. On these bases, we state the following hypothesis:

Hos: Customer technology adoption does not significantly influence the relationship between internet banking service quality and customer retention in deposit money banks in Rivers State.

\section{Empirical Review}

Many studies have provided empirical evidence concerning the relationship between internet banking service quality and customer retention (Al-Ajam\&MdNor, 2015;Al-Hawari\& Ward, 2006; Asad, Mohajerani\&Nourseresh, 2016; Asiyanbi\&Ishola, 2018; Devi \&Revathy, 2011;Liao \& Cheung, 2002). For example,Ramseook-Munhurrun and Naidoo (2011) found that there is a 
Vol. 8, Issue 3, pp.29-53 May, 2020

Published by ECRTD- UK

Print ISSN: 2053-4043(Print), Online ISSN: 2053-4051(Online)

significant relationship between e-banking service quality and e-customer loyalty in internet banking.Similarly, Rezaei, Amin \& Wan Ismail(2014). found that customer satisfaction and retention is a direct antecedent of positive e-banking service outcomes, and leads to positive customer loyalty (Sharma \&Malviya, 2014; Sharma, 2011; Siddique, Karim \& Rahman, 2011).and behavioral intention (Sikdar, Kumar\&Makkad,2015; Suzanne Harrison, Peter Onyia\&Tagg, 2014; Thakur, 2014). It seems that consumers who are satisfied with internet banking service quality are more likelyto engage in a consistent relationship with internet banking activities in future and demonstrate a more loyal behavior (Al-alak, 2014; Rod, Ashill, Shao \& Carruthers, 2009; Sharma \&Malviya, 2014). However, when dissatisfaction is felt,customers are likely to complain about the service and engage in negative word of mouth reactions and consequently poor patronage (Yoon \& Steege, 2013; Agarwal, Rastogi \& Mehrotra, 2009; Al-Ajam \& MdNor, 2015). and they will reactnegatively and switch to other service providers (Al-Somali, Gholami\& Clegg, 2008; Angelakopoulos\&Mihiotis, 2011; Arbore \& Busacca, 2009). In this sense, if the internet banking services fails to provide channels which the customers need, they will face moredifficulty in developing a relationship with their customers (Asiyanbi \& Ishola, 2018; Chemingui, 2013; Chiou \& Shen, 2012). As a result, customer who are satisfied with internet banking willexhibit high loyalty toward their bank. For this reason, internet banking service quality isconsidered as important determinant of customer retention. Based on our empirical referent, it is evident that none of the empirical studies above has empirically demonstrated the relationship between internet banking service quality and customer retention using the specific dimensions and measures adopted in this study, this thus leaves a gap in literature which this present empirical study intends to fill.

\section{METHODOLOGY}

Our study adopted quasi-experimental research design which employed cross sectional survey approach. Sullivan (2001) asserts that a survey "is a data collection technique in which information is assembled from individuals by having them respond to questions or statements". Survey method is also useful because it supports our triangulations of methodology as Sullivan (2001) believes that some survey methods allow for the use of both questionnaire and other data collection techniques like informal discussion, documented evidence. Besides, the quasi-experimental research design was adopted due to the complex relationship that exists between the study variables. From the submission of Nachmias and Nachmias (1996), this choice is informed by the fact that the researcher does not have perfect control of the variables that could affect the study. Therefore, a non-contrived research setting was adopted. Our population consisted of all money deposit bank customers in the 19 deposit money banks in Rivers State. The researcher purposively administers twenty (10) copies of questionnaire to customers in each of the nineteen (19) deposit money banks in Rivers State. This gave a total of One hundred and ninety (190) copies. 
Vol. 8, Issue 3, pp.29-53 May, 2020

Published by ECRTD- UK

Print ISSN: 2053-4043(Print), Online ISSN: 2053-4051(Online)

Table 3.1: List of Quoted Banks in Rivers State

\begin{tabular}{|l|l|l|}
\hline S/No. & Names of Quoted Banks in Rivers State & $\begin{array}{l}\text { Number to be given } \\
\text { each bank customers }\end{array}$ \\
\hline 1 & Unity Bank Plc & 10 \\
\hline 2 & Citibank Nigeria & 10 \\
\hline 3 & Wema Bank Plc & 10 \\
\hline 4 & Zenith Bank Plc & 10 \\
\hline 5 & Heritage Bank & 10 \\
\hline 6 & Keystone Bank & 10 \\
\hline 7 & Union Bank & 10 \\
\hline 8 & Standard chartered bank & 10 \\
\hline 9 & Access/Diamond Bank Plc & 10 \\
\hline 10 & Ecobank Plc & 10 \\
\hline 11 & Suntrust Bank Plc & 10 \\
\hline 12 & First City Monument Bank (FCMB) & 10 \\
\hline 13 & Fidelity Bank Plc & 10 \\
\hline 14 & First Bank Plc & 10 \\
\hline 15 & Guarantee Trust Bank Plc & 10 \\
\hline 16 & Polaris Bank Plc & 10 \\
\hline 17 & Stanbic Bank & 10 \\
\hline 18 & Sterling Bank & 10 \\
\hline 19 & United Bank of Africa (UBA) & 10 \\
\hline & TOTAL & $\mathbf{1 9 0}$ \\
\hline
\end{tabular}

Source: Nigerian Stock Exchange; September, 2019

The instruments used for data collection was the questionnaire. For the purpose of this study, a self-administered, questionnaire was employed. The questionnaire was structured into sections A and B. Section A dealt with the demographics of the respondents, while section B dealt with the study variables. The questions were designed in a simple format to ease administration. Multiple choice methods were adopted in framing the questions and the questions were structured using five-point Likert scale which solicited information from the customers of the bank chosen for the study.

In this study, we adopted an inferential statistical tools with statistical package for social sciences (SPSS) version 21.0 facilitating the analysis. The Spearman's Rank (rho) correlation was used to analyze the relationship between the independent and dependent variables at $\mathrm{P}>0.01$ (two-tailed test). Only one hundred and sixty-nine copies of the research questionnaire were valid, these copies were used for the analysis.

\section{DATA ANALYSIS AND RESULTS}

The dimensions of internet banking service quality: service efficiency and website design, were correlated against the measures of the dependent variable which is customer patronage (referral 
Vol. 8, Issue 3, pp.29-53 May, 2020 Published by ECRTD- UK

Print ISSN: 2053-4043(Print), Online ISSN: 2053-4051(Online)

and resistance to competitive pressure). The aim was to ascertain if there is a significant relationship between these dimensions of internet banking service quality and the measures of customer patronage, and the direction of such relationship. The Kendall's correlation coefficient statistics was used in analyzing the data collected for the purpose of this study, this was done with the aid of Statistical Package for Social Sciences (SPSS) version 20.

\section{Hypothesis One}

$\mathrm{HO}_{1}$ : There is no significant relationship between service efficiency and referral in deposit money banks in Rivers State.

\section{Statistical Analysis for Hypothesis One}

Table 4.1:Correlation Coefficient Result for Hypothesis One

\begin{tabular}{|lll|l|l|}
\hline & & Service & Referral \\
Efficiency & \\
\hline \multirow{2}{*}{ Kendall's tau_b } & Service & Correlation Coefficient & 1.000 & .823 \\
& & Sig. (2-tailed) &. & .018 \\
& & $\mathrm{~N}$ & 169 & 169 \\
& Referral & Correlation Coefficient & .823 & 1.000 \\
& & Sig. (2-tailed) & .018 & 169 \\
\hline
\end{tabular}

Source: Desk Research, 2019

From the result of the above table, the correlation coefficient $(r=0.823)$ between Service efficiency and referral revealed the existence of a strong positive relationship. The coefficient of determination $(\mathrm{r}=0.677)$ indicated that only $68 \%$ of referral is explained by service efficiency. The significant value of $0.018(\mathrm{p}<0.05)$ revealed that the relationship between service efficiency and referral is significant. Based on the outcome of the analysis above, we thus conclude that there is a positive and significant relationship between service efficiency and referral in deposit money banks in Rivers State.

\section{Hypothesis Two}

$\mathrm{HO}_{2}$ : There is no significant relationship between service efficiency and resistance to competitive pressure in deposit money banks in Rivers State. 
Vol. 8, Issue 3, pp.29-53 May, 2020

Published by ECRTD- UK

Print ISSN: 2053-4043(Print), Online ISSN: 2053-4051(Online)

Statistical Analysis for Hypothesis Two

Table 4.2: Correlation Coefficient Result for Hypothesis Two

\begin{tabular}{|c|c|c|c|c|}
\hline & & & $\begin{array}{l}\text { Service } \\
\text { Efficiency }\end{array}$ & $\begin{array}{l}\text { Resistance } \\
\text { Competitive } \\
\text { Pressure }\end{array}$ \\
\hline \multirow{6}{*}{ Kendall's tau_b } & \multirow{3}{*}{\multicolumn{2}{|c|}{$\begin{array}{c}\text { Correlation Coefficient } \\
\text { Service Efficiency Sig. (2-tailed) } \\
\mathrm{N}\end{array}$}} & \multirow[t]{2}{*}{1.000} & .861 \\
\hline & & & & .045 \\
\hline & & & 169 & 169 \\
\hline & Resistance & to Correlation Coefficient & .861 & 1.000 \\
\hline & Competitive & Sig. (2-tailed) & .045 & \\
\hline & Pressure & $\mathrm{N}$ & 169 & 169 \\
\hline
\end{tabular}

Source: Desk Research, 2019

From the result of the above table, the correlation coefficient $(r=0.861)$ between service efficiency and resistance to competitive pressure revealed the existence of a strong positive relationship. The coefficient of determination $(\mathrm{r}=0.741)$ indicated that $74.1 \%$ of customers' resistance to competitive pressure is explained by service efficiency. The significant value of $0.045(\mathrm{p}<0.05)$ revealed the existence of a significant relationship. Based on the above therefore, the null hypothesis two was rejected. Thus, we conclude that there is a positive and significant relationship between service efficiency and resistance to competitive pressure in deposit money banks in Rivers State.

\section{Hypothesis Three}

$\mathrm{HO}_{3}$ : There is no significant relationship between website design and referral in deposit money banks in Rivers State.

\section{Statistical Analysis for Hypothesis Three}

Table 4.3: Correlation Coefficient Result for Hypothesis Three

\begin{tabular}{|cll|l|l|}
\hline & & & Website Design & Referral \\
\hline \multirow{3}{*}{ Kendall's tau_b } & Website & Correlation Coefficient & 1.000 & .886 \\
& & Sig. (2-tailed) &. & .020 \\
& & $\mathrm{~N}$ & 169 & 169 \\
& Refign & Correlation Coefficient & .886 & 1.000 \\
& & Sig. (2-tailed) & .020 & 169 \\
\hline
\end{tabular}

Source: Desk Research, 2019

From the result of the above table, the correlation coefficient $(r=0.886)$ between website design and referral revealed a strong positive relationship. The coefficient of determination $(r=0.785)$ indicated that $78.5 \%$ of customers' referral is explained by website design of the banks. The significant value of $0.020(\mathrm{p}<0.05)$ also revealed the existence of a significant relationship. Based on the result above, the null hypothesis was rejected. Therefore, there is a positive and significant relationship between website design and referral in deposit money banks in Rivers State. 
Vol. 8, Issue 3, pp.29-53 May, 2020

Published by ECRTD- UK

Print ISSN: 2053-4043(Print), Online ISSN: 2053-4051(Online)

\section{Hypothesis Four}

$\mathrm{HO}_{4}$ : There is no significant relationship between website design and resistance to competitive pressure in deposit money banks Rivers State.

Statistical Analysis for Hypothesis Four

Table 4.4:Correlation Coefficient Result for Hypothesis Four

\begin{tabular}{|c|c|c|c|c|}
\hline & & & Website Design & $\begin{array}{l}\text { Resistance to } \\
\text { Competitive } \\
\text { Pressure }\end{array}$ \\
\hline \multirow{6}{*}{ Kendall's tau_b } & & Correlation Coefficient & 1.000 & .914 \\
\hline & Website Design & Sig. (2-tailed) & & .017 \\
\hline & & $\mathrm{N}$ & 169 & 169 \\
\hline & Resistance & to Correlation Coefficient & .914 & 1.000 \\
\hline & Competitive & Sig. (2-tailed) & .017 & \\
\hline & Pressure & $\mathrm{N}$ & 169 & 169 \\
\hline
\end{tabular}

Source: Desk Research, 2019

From the result of the above table, the correlation coefficient $(r=0.914)$ between website design and resistance to competitive pressure showed a strong positive relationship. The coefficient of determination $(\mathrm{r}=0.835)$ indicated that $83.5 \%$ of customers' resistance to competitive pressure is explained by website design. Also, the significant value of $0.017(\mathrm{p}<0.05)$ revealed the existence of a significant relationship. Based on the above, the null hypothesis was rejected. Therefore, there is a positive and significant relationship between website design and resistance to competitive pressure in deposit money banks in Rivers State.

Hypothesis Five (Hos): Customer Technology Adoption does not significantly moderate the relationship between internet banking service quality and customer retention 
Vol. 8, Issue 3, pp.29-53 May, 2020

Published by ECRTD- UK

Print ISSN: 2053-4043(Print), Online ISSN: 2053-4051(Online)

Table 4.5: SPSS correlation result for hypothesis ten

\begin{tabular}{|c|c|c|}
\hline Control variable & $\begin{array}{l}\text { Internet } \\
\text { Banking } \\
\text { Service } \\
\text { Quality }\end{array}$ & $\begin{array}{l}\text { Customer } \\
\text { Retention }\end{array}$ \\
\hline 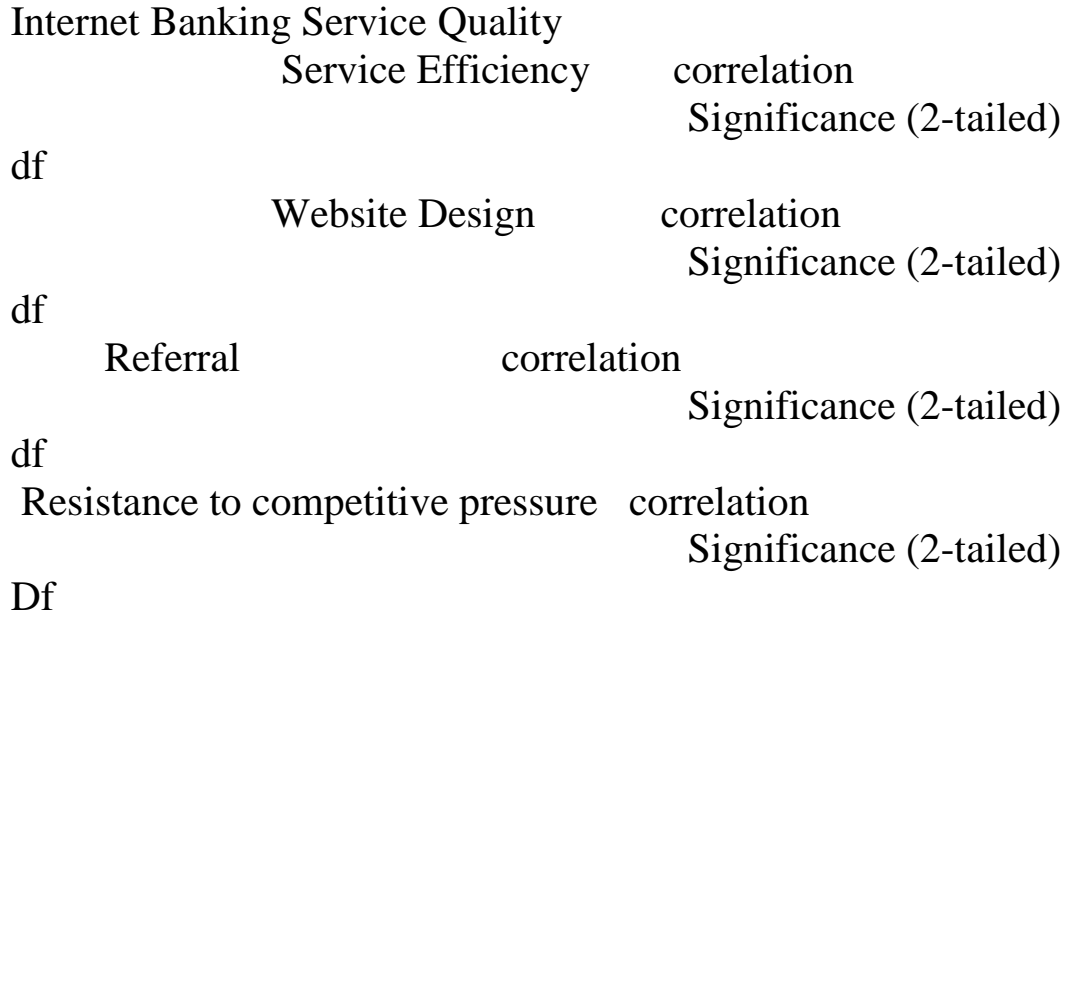 & $\begin{array}{ll}1.000 & \\
& \\
& \\
.976 \\
.005 \\
2 \\
.886 \\
.002 \\
.969 \\
.004 \\
2\end{array}$ & $\begin{array}{c}.976 \\
.005 \\
2 \\
1.000 \\
0 \\
0 \\
.897 \\
.121 \\
2 \\
.966 \\
.001 \\
2\end{array}$ \\
\hline
\end{tabular}

Source: SPSS Output (based on 2019 field survey data)

From the result of the partial correlation, the correlation coefficient between service efficiency and referral (0.886), service efficiency and resistance to competitive pressure ( $r=0.969)$, website design and referral (0.897), website design and resistance to competitive pressure (0.966), with significant value (2-tailed) of 0.001. Customer technology adoption as the moderating variable was significant with all the variables. Based on that, the null hypothesis was rejected. Therefore, customer technology adoption significantly moderates the relationship between internet banking service quality and customer retention in deposit money banks in Rivers State.

\section{DISCUSSION OF FINDINGS}

\section{Relationship between Internet Banking Service Efficiency and Customer Retention}

From the result of the analysis, the correlation coefficient ( $r=0.823)$ and $(r=0.861)$, was tested at a 0.05 significant level, the outcome revealed that there is a positive and significant correlation between service efficiency and referral, service efficiency and resistance to competitive pressure. Therefore, efficiency in the internet banking services of the deposit money banks can play a 
Vol. 8, Issue 3, pp.29-53 May, 2020

Published by ECRTD- UK

Print ISSN: 2053-4043(Print), Online ISSN: 2053-4051(Online)

significant role in customers' retention. Al-Hawari\& Ward (2006) had mentioned that perceived efficiency in E-banking facilities, convenient and secure website location, and user-friendly internet system, speed, minimum web errors, high uptime and service coverage speed are essential service quality aspects of e-banking efficiency. The increased adoption of internet in the banking sector has made the issue of technology relevance important. At present, there has been a wider use of internet banking services across banks with high expectations from the customers that these e-banking services will be efficient enough to provide the desired satisfaction which customer expects from the Banks in the use of these internet banking services.

\section{Relationship between Internet Banking Website Design and Customer Retention}

From the result of the analysis, the correlation coefficient $(r=0.886)$ and $(r=0.914)$ was tested at a 0.05 significant level, the outcome revealed that there is a positive and significant correlation between website design and referral; website design and resistance to competitive pressure. With reference to the findings, (Asad, Mohajerani \& Nourseresh, 2016) highlighted that customers can request information and perform most banking services like account balance inquiry, inter-account transfers, and bill-payment via the Internet with ease if the banks carefully design their web in simplicity. Agarwal, Rastogi and Mehrotra, (2009) also concur that Internet banking is a web application based on client/server architecture in which Internet technology plays an important role and a simple web enables customers enjoy the benefits of the E-banking platform.

This study discovered a significant relationship between service efficiency and referral in deposit money banks in Rivers State; a significant relationship between service efficiency and resistance to competitive pressure in deposit money banks in Rivers State; a significant relationship between website design and referral in deposit money banks in Rivers State; a significant relationship between website design and resistance to competitive pressure in deposit money banks in Rivers State; a significant influence of customer technology adoption on the relationship between internet banking service quality and customer retention in deposit money banks in Rivers State

\section{CONCLUSION AND RECOMMENDATIONS}

\section{Conclusion}

Based on the finding as revealed by the study, the following conclusions are made:

i.) A positive and significant relationship exists between internet banking service efficiency and referral in deposit money banks in Rivers State

ii.) Internet banking service efficiency influences customers' resistance to competitive pressure in deposit money banks in Rivers State

iii.) There is a positive and significant relationship between internet banking website design and referral in deposit money banks in Rivers State.

iv.) There is a positive and significant relationship between internet banking website design and resistance to competitive pressure in deposit money banks in Rivers State.

v.) Customer technology adoption positively influences the relationship between internet banking service quality and customers' retention in deposit money banks in Rivers State. 
British Journal of Marketing Studies (BJMS)

Vol. 8, Issue 3, pp.29-53 May, 2020

Published by ECRTD- UK

Print ISSN: 2053-4043(Print), Online ISSN: 2053-4051(Online)

\section{Recommendations}

In accordance with the conclusions above, the researcher therefore recommends that:

i. $\quad$ Banks should invest more on internet technologies that will ensure efficiency in serving customer and overall satisfactions of the customers on line needs.

ii. Banks should have adequate budgets for the development of internet banking infrastructure (such as effective web design) to ensure easy access presence in providing solutions to the internet banking requirements of their valued customers.

iii. There is need for the banks to create an active platform where they can listen to the internet banking challenges of their customers and proffer swift solutions to such problems, because it is only when the banks attend to the emerging challenges of their customers that sustained patronage and customers' retention can be guaranteed.

\section{References}

Ab.Aziz, M. R., Shukor, S. A., \& Abdullah, W. W. M. Z. (2014). A specific analysis of service quality dimensions on customer satisfaction and customer loyalty: A study of AlIjarahThumma Al-Bai' (AITAB) and vehicle financing-i (Bai' BithamanAjil- BBA). Journal of Emerging Issues in Economics, Finance and Banking (JEIEFB); An Online International Monthly Journal, 3(2), 133-139.

Agarwal, R., Rastogi, S., \&Mehrotra, A. (2009). Customers' perspectives regarding E-Banking in an emerging economy. Journal of Retailing and Consumer Services, 16, 340-351.

Akhtar, M. N., Hunjra, A. I., Akbar, S. W., Rehman, K. U., \&Niazi, C. S. K. (2011). Relationship between customer satisfaction and service quality of Islamic banks. World Applied Sciences Journal, 13(3), 453-459.

Al-Ajam, A.S., \&MdNor, K. (2015). Challenges of adoption of internet banking service in Yemen. International Journal of Bank Marketing, 33(2), 178-194.

Al-alak, B.A. (2014). Impact of marketing activities on relationship quality in the Malaysian banking sector. Journal of Retailing and Consumer Services, 21(3), 347-356.

Alawneh, A., Al-Refai, H., \&Batiha, K. (2013). Measuring user satisfaction from e-Government services: Lessons from Jordan. Government Information Quarterly, 30, 277-288.

Al-Hawari\& Ward, T. (2006). The effect of automated service quality on Australian banks' financial performance and the mediating role of customer satisfaction. Marketing Intelligence \& Planning, 24(2), $127-147$

Alsajjan, B., \& Dennis, C. (2010). Internet banking acceptance model: cross-market examination. Journal of Business Research, 63(9), 957-963.

Al-Somali, S. A, Gholami, R., \& Clegg, B. (2008). Internet banking acceptance in the context of developing countries: An extension of the technology acceptance model.

Angelakopoulos, G., \&Mihiotis, A. (2011). E-banking: Challenges and opportunities in the Greek banking sector. Electronic Commerce Research, 11(3), 297-319.

Arbore, A., \&Busacca, B. (2009). Customer satisfaction and dissatisfaction in retail banking: Exploring the asymmetric impact of attribute performances. Journal of Retailing and Consumer Services, 16(4), 271-280.

Asad, M. M., Mohajerani, N. S., \&Nourseresh, M. (2016). Prioritizing factors affecting customer satisfaction in the inter-net banking system based on cause and effect relationships. Procedia Economics and Finance, 36, 210-219. 
British Journal of Marketing Studies (BJMS)

Vol. 8, Issue 3, pp.29-53 May, 2020

Published by ECRTD- UK

Print ISSN: 2053-4043(Print), Online ISSN: 2053-4051(Online)

Asiyanbi, H., \&Ishola, A. (2018). E-Banking services impact and customer satisfaction in selected bank branches in Ibadan metropolis, Oyo state, Nigeria. Accounting, 4(4), 153-160.

Bei, L. T., \&Chiao, Y. C. (2006). The determinants of customer loyalty: An analysis of intangible factors in three service industries. International Journal of Commerce and Management, $16,162-177$.

Bhattacherjee, A. (2001). An empirical analysis of the antecedents of electronic commerce service continuance. Decision Support Systems, 32(2), 201-214.

Brockner, J., Higgins, E.T., \& Low, M.B. (2004). Regulatory focus theory and the entrepreneurial process.Journal of Business Venturing,19(2), 203-220.

Calisir, F., \&Gumussoy, C.A. (2008). Internet banking versus other banking channels: Young consumers' view. International Journal of Information Management, 28(3), 215-221.

Chaoprasert, C., \& Elsey, B. (2004). Service quality improvement in Thai retail banking and its management implications. ABAC Journal, 24(1), 47-66.

Chaoprasert, C., \& Elsey, B. (2004). Service quality improvement in Thai retail banking and its management implications. ABAC Journal, 24(1), 47-66.

Chemingui, H. (2013). Resistance, motivations, trust and intention to use mobile financial services. International Journal of Bank Marketing, 31(7), 574-592.

Chen, M.-Y., \&Teng, C.-I. (2013). A comprehensive model of the effects of online store image onpurchase intention in an e-commerce environment. Electronic Commerce Research, 13(1), 1-23.

Chen, R.-F., Hsiao, J.-L. \& Hwang, H.-G. (2012). Measuring customer satisfaction of Internebanking in Taiwan: scale development and validation. Total Quality Management \&Business Excellence,23(7/8), 749-767.

Chiou, J.-S., \& Shen, C.-C. (2012). The antecedents of online financial service adoption: Theimpact of physical banking services on Internet banking acceptance. Behaviour\&Information Technology, 31(9), 859-871.

Culiberg, B., \&Rojšek, I. (2010). Identifying service quality dimensions as antecedents to customer satisfaction in retail banking. Economic and Business Review, 12(3), 151-166.

Datta, S. K. (2010). Acceptance of E-Banking among adult customers: An empirical investigation in India. Journal of Internet Banking and Commerce, 15(2), 1-17.

Davies, F. (1989). Perceived usefulness, perceived ease of use and user acceptance of information technology. MIS Quarterly, 13(3), 318-339.

Devi, S. K., \&Revathy, B. (2011). Customers 'satisfaction with service quality of internet banking. International Journal of Business Policy and Economic, 4(1), 161-176

DeYoung, R., Lang, W.W., \&Nolle, D.L. (2007). How the internet affects output and performance at community banks.Journal of Banking \& Finance, 31(4), 1033-1060.

Dodds, W.B., Monroe, K.B., \& Grewal, D. (1991). Effects of price,brand and store information on buyers' product evaluations. Journal of Marketing Research, 24(28), 307-319.

Eriksson, K., Kerem, K., \& Nilsson, D. (2005). Customer acceptance of Internet banking in Estonia. International Journal of Bank Marketing, 23(2), 200-216.

Fishbein, M., \&Ajzen, I. (1975). Belief, attitude, intention, and behavior. Reading, M.A: AdditionWesley. 
British Journal of Marketing Studies (BJMS)

Vol. 8, Issue 3, pp.29-53 May, 2020

Published by ECRTD- UK

Print ISSN: 2053-4043(Print), Online ISSN: 2053-4051(Online)

Fonseca, J.R. (2014). E-banking culture: A comparison of EU 27 countries and Portuguese case inthe EU 27 retail banking context. Journal of Retailing and Consumer Services,21(5), 708-716.

Friedman, R. S., \& Forster, J. (2001). The effects of promotion and prevention cues on creativity. Journal of Personality and Social Psychology,81(6), 1001-1013.

Giordani, G., Floros, C., \& Judge, G. (2014). Econometric investigation of internet bankingadoption in Greece. Journal of Economic Studies, 41(4), 586-600.

Gronroos, C. (1998). Marketing services: The case of a missing product. Journal of Business \& Industrial Marketing, 13, 322-338.

Guriting, P., \&Ndubisi, N.O. (2006). Borneo online banking: Evaluating customer perceptions and behavioural intention. Management Research News, 29(1/2), 6-15.

Hanafizadeh, P., Keating, B.W., \&Khedmatgozar, H.R. (2014). A systematic review of internet banking adoption. Telematics and Informatics, 31(3), 492-510.

Harrison, T.S., Onyia, O.P., \&Tagg, S.K. (2014). Towards a universal model of internet bankingadoption: initial conceptualization. International Journal of Bank Marketing, 32(7), 647-687.

Hasim, M.S., \& Salman, A. (2010). Factors affecting sustainability of internet usage among youth. The Electronic Library,28(2), 300-313.

Ho, S. H., \&Ko, Y. Y. (2008). Effects of self-service technology on customer value and customer readiness: The case of Internet banking. Internet Research, 18, 427-446.

Hossain, M., \& Leo, S. (2009). Customer perception on service quality in retail banking in Middle East: the case of Qatar. International Journal of Islamic and Middle Eastern Finance and Management, 2(4), $338-350$.

Islam, N., \&Ahmed, E. (2003). A measurement of customer service quality of banks in Dhaka City of Bangladesh. South Asian Journalof Management, 12(1), 37-57.

Jain, S. K., \& Gupta, G. (2004). Measuring service quality: SERVQUAL vs. SERVPERF scales. Vikalpa, 29(2), 25-38.

Jayawardhena, C. (2004). Measurement of service quality in internet banking: The development of an instrument. Journal of Marketing Management, 20(1/2),185-207.

Jelena, T., Natalja, L.,\&Konstantins, K. (2013). Service quality in banking: developing and testing measurement instrument with Latvian sample data. ActaUniversitatisAgriculturae et SilviculturaeMendelianaeBrunensis. 11(2), 507-515.

Johns, N., \&Tyas, P. (1996).Investigating of the perceived components of the meal experience, using perceptual gap methodology. Progress in Tourism and Hospitality Research, 2(1), 15-26. International Journal of Contemporary Hospitality Management, 11(5),205-222.

Jun, M., \&Cai, S. (2001). The key determinant of internet banking services quality: A content analysis.International Journal of Bank Marketing, 19(7), 276-291.

Jun, M., Yang, Z., \& Kim, D. (2004). Customers' perceptions of online retailing service quality and their satisfaction. International Journal of Quality \& Reliability Management, 21, 817840.

Kadir, H. A., Rahmani, N., \&Masinaei, R. (2011). Impacts of service quality on customer satisfaction: Study of online banking and ATM services in Malaysia. International Journal of Trade, Economics and Finance, 2(1), 1-9. 
British Journal of Marketing Studies (BJMS)

Vol. 8, Issue 3, pp.29-53 May, 2020

Published by ECRTD- UK

Print ISSN: 2053-4043(Print), Online ISSN: 2053-4051(Online)

Karjaluoto, H., Mattila, M., \&Pento, T. (2002). Factors underlying attitude formation towards online banking in Finland. International Journal of BankMarketing, 20(6), 261-272.

Khalfan, A. M., \&Alshawaf, A. (2004). Adoption and implementation problems of E-Banking: A study of the managerial perspective of the banking industry in Oman. Journal of Global Information Technology Management, 7(1), 47-64.

Khalil, N., Sutanonpaiboon, J., \&Mastor, N.H. (2010). Malay, Chinese, and internet banking. Chinese Management Studies, 4(2), 141-153.

Kivela, J., Inbakaran, R., \& Reece, J. (1999). Consumer research in the restaurant environment, Part 1: A conceptual model of dining satisfaction and return patronage.

Laforet, S., \& Li, X. (2005). Consumers'attitudes towards online and mobile banking in China. International Journal of Bank Marketing, 23(5), 362-380.

Lassar, W. M., Manolis, C., \& Winsor, R. D. (2000). Service quality perspectives and satisfaction in private banking. Journal of Services Marketing, 14(3), 244-271.

Lassar, W.M., Manolis, C., \&Lassar, S.S. (2005). The relationship between consumer innovativeness, personnel characteristics, and online banking adoption. International Journal of Bank Marketing, 23(2), 176-199.

Lee, A. Y., \&Aaker, J. L. (2004). Bringing the frame into focus:The influence of regulatory fit on processing fluency and persuasion. Journal of Personality and Social Psychology, 86, 205218.

Liao, Z., \& Cheung, M. T. (2002). Internet-based E-Banking and consumer attitudes: An empirical study. Information \& Management, 39, 283-295.

Li-hua, Y. (2012). Customer satisfaction antecedents within service recovery context: evidencesfrom'Big 4' banks in China. Nankai Business Review International, 3 (3), 284301.

Liu, C.-h., Jing, J., \& Huang, L. (2005). Internet banking: Strategic responses to the accession of WTO by Chinese banks.Industrial Management \& Data Systems, 105(4),429-442.

Lockwood, P., Jordan, C. H., \&Kunda, Z. (2002). Motivation by positive or negative role models: Regulatory focus determines who will best inspire us. Journal of Personality and Social Psychology, 83(4), 854-864.

Lustsik, O. (2004, November). Can e-banking services be profitable? (University of Tartu Economics and Business Administration Working Paper No.30-2004). doi:10.2139/ssrn.612762

Malek, A., Nik, K.\& Nik Mat (2011). Modelling the antecedents of Internet banking service adoption (IBSA) in Jordan: A structural equation modeling (SEM) approach. Journal of Internet Banking and Commerce, 16(1), 1-13.

McNeish, J. (2015). Consumer trust and distrust: Retaining paper bills in online banking. International Journal of Bank Marketing, 33(1), 5-22.

Mefford, R. N. (1993). Improving service quality: Learning from manufacturing.International Journal of Production Economics, 30, 399-413.

Mishra, A. A. (2009), "A study on customer satisfaction in Indian retail banking.IUP Journal of Management Research, 8(11), 45-61.

Mols, N .P. (2000). The Internet and services marketing the case of Danish retail banking Internet Research. Electronic Networking Applications and Policy, 10(1), 7-18. 
British Journal of Marketing Studies (BJMS)

Vol. 8, Issue 3, pp.29-53 May, 2020

Published by ECRTD- UK

Print ISSN: 2053-4043(Print), Online ISSN: 2053-4051(Online)

Nagabhushanam, M. (2011). A study on customer service quality of banks in India. Journal of Analyz Research Solutions, 315-364.

Narayanasamy, K., Rasiah, D., \& Tan, T.M. (2011). The adoption and concerns of e-finance in Malaysia. Electronic Commerce Research, 11(4), 383-400.

Nor, K.M., \& Pearson, J.M. (2008). An exploratory study into the adoption of internet banking in a developing country: Malaysia. Journal of Internet Commerce, 7(1), 29-73.

Oliver, R. L. (1999). Whence consumer loyalty? The Journal of Marketing, 63, 33-44.

Parasuraman, A. (2000). Technology readiness index (TRI): A multiple-item scale to measure readiness to embrace new technologies. Journal of Service Research, 2(4), 307-20.

Parasuraman, A., \& Grewal, D. (2000). The impact of technology on the quality value loyalty chain: A research agenda. Journal of Academy of Marketing Science, 28(1), 168-174.

Parasuraman, A., Zeithaml, V. A., \& Berry, L. L. (1985). A conceptual model of service quality and its implications for future research. The Journal of Marketing, 49(4), 41-50.

Parasurman, A.,Zeithaml, V. A., \& Berry, L. L. (1988). SERVQUAL: A multiple- item scale for measuring consumer perceptions of service quality.Journal of Retailing, 64(1), 12-40.

Poon, W. C. (2007). Users' adoption of E-Banking services: The Malaysian perspective. Journal of Business \& Industrial Marketing, 23, 59-69.

Radomir, L., Wilson, A., \&Mircea, S. A. (2011). Improving Bank Quality Dimensions to Increase Customer Satisfaction. Management and Marketing Journal, 9(1), 126-148.

Rajput, N., \& Gupta, M. (2011). Impact of IT on Indian commercial banking industry: DEA Analysis. Global Journal of Enterprise Information System, 3(1),17-31.

Ranaweera, C., \& Neely, A. (2003). Some moderating effects on the service quality-customer retention link. International Journal of Operations \& Production Management, 23, 230248.

Rezaei, S., Amin, M., \& Wan Ismail, W.K. (2014). Online re-patronage intention: an empiricalstudy among Malaysian experienced online shoppers. International Journal of Retail \&Distribution Management, 42(5), 390-421.

Ribbink, D., Van Riel, A.C., Liljander, V., \&Streukens, S. (2004). Comfort your online customer:Quality, trust and loyalty on the internet. Managing Service Quality, 14(6), 446456.

Rod, M., \&Ashill, N.J. (2010). Management commitment to service quality and service recoveryperformance: A study of frontline employees in public and private hospitals. InternationalJournal of Pharmaceutical and Healthcare Marketing, 4(1), 84-103.

Rod, M., Ashill, N.J., Shao, J., \& Carruthers, J. (2009). An examination of the relationshipbetween service quality dimensions, overall internet banking service quality and customersatisfaction: A New Zealand study. Marketing Intelligence \& Planning, 27(1),103-126.

Rogers, E.M., \& Shoemaker, F.F. (1971). Communication of innovations. The Free Press, New York.

Santos, J. (2003). E-service quality: A model of virtual service quality dimensions. ManagingService Quality, 13(3), 233-246.

Schneider, B., \& White, S. (2004). Service quality research perspectives. Thousand Oaks: CA: Sage. 
British Journal of Marketing Studies (BJMS)

Vol. 8, Issue 3, pp.29-53 May, 2020

Published by ECRTD- UK

Print ISSN: 2053-4043(Print), Online ISSN: 2053-4051(Online)

Sharma, G., \&Malviya, S. (2014). Internet banking service quality and its impact on customer satisfaction in Indore district of Madhya Pradesh. International Journal of Business and Management Invention, 3(3), 1-6.

Sharma, H. (2011). Bankers' perspectives on E-Banking. Global Journal of Research in Management, 1(1), 71-85.

Shih, Y., \& Fang, K. (2003). The use of the decomposed theory of planned behavior to study Internet banking in Taiwan. Internet Research Electronic Network Application Policy, 14(3), 213-223.

Siddique, A. B., Karim, K. S., \& Rahman, M. L. (2011). Customers' perception about the determinants of service quality of foreign and domestic banks: An empirical study on Bangladesh. Journal of Business and Technology, 1-14.

Sikdar, P., Kumar, A., \&Makkad, M. (2015). Online banking adoption: A factor validation and satisfaction causation study in the context of Indian banking customers. International Journal of Bank Marketing, 33, 760-785.

Sulek, J. M., \&Hensley, R. L. (2004). The relative importance of food, atmosphere and fairness of wait. Cornell Hotel and Restaurant Administration Quarterly, 45(3), 235-247

Suzanne Harrison, T., Peter Onyia, O., \&Tagg, S.K. (2014). Towards a universal model ofinternet banking adoption: initial conceptualization. International Journal of BankMarketing, 32(7), 647-687.

Thakur, R. (2014). What keeps mobile banking customers loyal? International Journal of BankMarketing, 32(7), 628-646.

Toor, A., Hunain, M., Hussain, T., Ali, S., \&Shahid, A. (2016). The impact of E-Banking on customer satisfaction: Evidence from banking sector of Pakistan. Journal of Business Administration Research, 5(2), 27-40.

Van Riel, A.C.R., Liljander, V., \&Jurriens, P. (2001), "Exploring consumer evaluations of eservices: a portal site. International Journal of Service Industry Management, 12(4), 35977.

Wei, L. C. (2013). Determinants of customer satisfaction in domestic retail banking sector. (Master of Business Administration), UniversitiTunku Abdul Rahman.

Weir, C.S., Anderson, J.N., \& Jack, M.A. (2006). On the role of metaphor and language in designof third party payments in e-banking: Usability and quality. International Journal ofHumanComputer Studies, 64(8), 770-784.

Wijayaratne, K. (2015). Expansion of internet banking-overcoming the barriers. 27th anniversary convention, 229-250.

Wirtz, J., \&Lwin, M.O. (2009). Regulatoryfocus theory, trust and privacy concern. Journal of Science Research, 12(2), 190-207.

Wu, Y.-L., Tao, Y.-H., \& Yang, P.-C. (2012). Learning from the past and present: measuringInternet banking service quality. The Service Industries Journal, 32(3), 477-497.

Wungwanit-Chakorn, A. (2000). Adoption intention of banks' customer on internet banking service. ABAC Journal, 22(3), 63-80.

Yang, Z., \& Fang, X. (2004). On line service quality dimensions and their relationships with satisfaction: A content analysis of customer reviews of securities brokerage services.International Journal of Service Industry Management, 15(3),302-326. 
Vol. 8, Issue 3, pp.29-53 May, 2020

Published by ECRTD- UK

Print ISSN: 2053-4043(Print), Online ISSN: 2053-4051(Online)

Yoon, H.S., \&Steege, L.M.B. (2013). Development of a quantitative model of the impact ofcustomers'personality and perceptions on internet banking use. Computers in HumanBehavior, 29(3), 1133-1141.

Zeithaml, V. A. (1988). Consumer perceptions of price, quality and value: A means-end model and synthesis of evidence.Journal of Marketing, 52(3), 2 - 22.

Zeithaml, V. A., \&Parasuraman, A. (2004). Service Quality. USA: Marketing Science Institute.

Zeithaml, V. A., Berry, L. L., \&Parasuraman, A. (1996). The behavioral consequences of service quality. Journal of Marketing, 60(2), 31-46.

Zeithaml, V. A., Parasuraman, A., \& Berry, L. L. (1990). Delivering quality service: Balancing customer perceptions and expectations. New York, NY: Free Press.

Zhao, A.L., Hanmer-Lloyd, S., Ward, P., \& Goode, M.M. (2008). Perceived risk and Chineseconsumers'internet banking services adoption. International Journal of Bank Marketing, 26(7), 505-525.

Zhao, A.L., Koenig-Lewis, N., Hanmer-Lloyd, S., \& Ward, P. (2010). Adoption of internetbanking services in China: is it all about trust? International Journal of Bank Marketing, 28(1), 726.

Zhou, L. (2004). A dimension-specific analysis of performance only measurement of service quality and satisfaction in China's retail banking. Journal of Services Marketing, 18, 534546. 